\title{
Cost accounting in Spanish and Catalan universities: Its current status of implementation
}

\author{
Ramon Saladrigues (iD), Anna Tena (D) \\ Universitat de Lleida (Spain) \\ ramon.saladrigues@aegern.udl.cat,tenat@,aegern.udl.es
}

Received October, 2016

Accepted November, 2016

Versión en español

\section{Abstract}

Purpose: The main purpose of this paper is to analyse the development, implementation and use of different cost systems at universities.

Design/methodology: First, the need for a system of costs has been justified. The main elements favouring the process of implementing a cost system have been identified.

Subsequently, through literature review, surveys from various agencies and interviews with those responsible for the cost management of universities, the degree of implementation of cost accounting in public universities, and whether or not there is any uniformity between different cost systems is analysed.

Findings: The disparity between systems is confirmed, and the elements are identified that contribute to both improving the cost accounting knowledge of higher education institutions and achieving a greater degree of approximation between different cost systems.

Research limitations/implications: The process of implementing cost systems in universities is not complete. It should be noted that the analysis is therefore performed during the implementation process. 
Practical implications: The results are interesting for university management professionals and information users. In addition, they will contribute to improving the efficiency of public resources.

Originality/value: This article provides up-to-date and timely information on a new tool that helps to improve university management.

Keywords: Cost Accounting, College costs, Educational costs, Research costs

Jel Codes: M41, H52, I23

\section{Cost accounting and Universities}

Given the current scenario for public and private universities, where they are competing more and more in the international arena to capture research and teaching talent; where they are competing to gain a good position in university rankings; where a high degree of transparency and accountability is required; and where resources have been reduced significantly, improved efficiency has become one of the main university aims.

Improving efficiency requires, inter alia,

- information on the costs and income of university units and centres;

- a cost and income analysis based on activities, not just according to units and cost centres, and;

- indicators that gauge the efficiency of the various activities run by the universities (teaching, research, technology transfer, third mission and university extension).

It is in this context that cost accounting becomes an essential tool for universities, and this explains the recent efforts focused on implementing cost analysis systems in universities (Estermann et al., 2013).

The process of implementing university cost analysis has accelerated in recent years, and two main factors have determined the advance of analytical accounting in universities. Firstly, the development of an Analytical Accounting Model for Public Universities in Spain: the Modelo de Contabilidad Analitica Normalizada de Organismos Autónomos model (the Standardised Analytical Accounting model of 
Autonomous Bodies) (CANOA, 2011). Secondly, Royal Decree 14/2012, of 20 April on rationalising public spending on education costs, so as to know the real cost of qualifications and determine the public prices, setting the legal compliance deadline up to university academic year 2015/16.

Other factors that have contributed to implementing cost accounting in universities include the advances in the Sistema Integrado de Información Universitario (Integrated University Information System) (SIIU) and the now consolidated UNEIX in the case of Catalonia, and the awareness that analytical accounting is becoming an important decision making element.

\section{Contribution of cost accounting and the indicators}

One of the main aims of cost accounting is to obtain appropriate information that enables improving an organisation's efficiency. Management accounting therefore appears as a valuable tool that allows more efficient planning, controlling and decision making.

Implementing management accounting systems requires, first, setting up cost models, which make it possible to determine the costs of these systems, and their income and level of coverage. This also reinforces the analysis of essential questions for managing these aspects.

In an environment of constant transformations such as those occurring in today's context, universities must adapt to the changes taking place around them (Bergevärn et al., 1995; Meyer \& Rowan, 1997). These changes, both in an organisation's environment and structure, also imply changes in information needs. Consequently, the way information is used to measure and motivate performance or decision making must also adapt to the new circumstances (Atkinson et al., 1997; Araujo 2003).

In this process, the accounting and management control system plays an important role, particularly in two aspects:

- Management can avail of the information potential of the accounting and management control system to implement the changes that bring the organisation in line with the new situation.

- The actual accounting and management control system can change to adapt to the new conditions.

Also, so that the control system can continually follow-up the organisation's evolution, the use of indicators is required. Therefore, it is necessary to identify and select the best control indicators for 
controlling the evolution of the university and the various teaching centres, departments and units. Consequently, these indicators can orientate the university's behaviour "a priori", and "a posteriori" they can provide a quantitative assessment of the management efficiency in each university, cost centre or organizational unit.

In this respect, the control indicators can be used to:

- Set the initial objectives that the various organisational units must aim for, and

- Assess "a posteriori" the action (of the responsible party) in each teaching centres, department or organisational unit.

Generally speaking, these indicators are just "objective measurements, usually quantitative ones, of an institution's achievements" or those of a whole system, such as, for example, a higher education system" (Ball \& Halwachi, 1987). When applied to the university sector, the indicators measure certain aspects of the university inputs, its functioning and results (Kells, 1991).

Once a consensus has been reached over the number and definition of the indicators, one of their main advantages is their objectivity and easy individual interpretation. The main difficulty, however, appears when trying to obtain an overall view of the performance of the assessed units.

Unfortunately, identifying the indicators measuring university outputs is a very difficult task, regarding teaching, research and third mission.

The same occurs with identifying the inputs due to the peculiar nature of the production processes in universities. In higher education, activities of a different nature are carried out simultaneously. So, most of the resources used are shared between the two activities, and this conditions the whole activity assessment process. Perhaps the best example are the labour costs of the teaching and research staff (PDI), because these costs focus on all the university activities (teaching, research and third mission).

Finally, as well as the difficulties mentioned above, we have the added complexity of the return on teaching from research and, generally, the unavoidable relationships produced between both activities: universities generate knowledge through research, whereby research reinvests in teaching and, on the other hand, universities disclose their knowledge through teaching. 


\section{The start of cost accounting in universities}

Cost accounting in universities is a relatively new concept. In fact, it was virtually non-existent in the middle of the 80s, when the CVCP committee (Committee of Vice-Chancellors and Principals) was set up, including most of the universities in the United Kingdom, to conduct a series of studies on management efficiency in universities. This committee concluded its work in 1985 with the publication of the report entitled: Report of the Steering Committee for Efficiency Studies in Universities, the socalled Jarrat Report. The Jarrat Report mainly highlights the lack of management accounting systems in universities and the need for these institutions to improve their information mechanisms, so that they can learn about the cost of their different centres, and therefore manage and control them more responsibly. Perhaps the main aspect of this report is that it defines a series of performance indicators that claim to be a management tool, instead of just an accountability instrument.

After the publication of this report, there was an initial response: a new work group was created in 1988 (CVCP, 1988) to be responsible for writing the guidelines to determine the total cost of the research, and also the cost of the other activities financed by public grants and even projects financed by external sources. This work group puts emphasis on learning about the total cost of all the activities carried out in the universities, whether they are financed publicly or by external sources. In addition, it establishes the recommendation that universities adopt complete costs systems based on methodologies coherent with the principles already accepted in industry and in other government centres.

Cost accounting developed differently in the US, although it was introduced around the same time. While the CVCP reports appeared in the United Kingdom, in the US the Budget and Management Office (BMO) provided a guide for using cost accounting in higher education institutions. Beforehand the relationship between the universities and the Federal Government was based on mutual trust and respect. However, it was after 1995 (Obester, 2001) when the universities receiving more than 25 million dollars in federal grants, or those included among the 99 top research institutions, were obliged to follow 4 of the 19 CAS standards set out by the Budget and Management Office (A-21) on cost accounting. The CAS (Cost Accounting Standards) refer to the cost accounting procedures and their disclosure. The four standards that the mentioned universities had to follow were those indicated below:

- CAS 501; coherence in estimating, accumulating and presenting the cost reports.

- CAS 502; coherence in locating a cost incurred for the same purpose. 
- CAS 505; do not register non-admissible costs.

- CAS 506; coherence in the cost accounting periods.

Until these standards were introduced, it was possible to use a cost accounting system separated into direct and indirect costs. However, since then, universities have been obliged to measure, accumulate, assign and distribute all kinds of costs, and not just the direct costs regarding a particular contract or project. Cost accounting began to consider all the activities in a university.

In the Spanish state, concern over calculating university costs began at the start of the 90s, driven by the Intervención General de la Administración del Estado (General Intervention by the State Administration) (IGAE). However, as we will see, the implementation process has been much slower.

Initially, projects like the SCAU model (Sistema de Contabilidad Analitica para Universidades, 1991) sprung up, which was created to obtain information that enabled identifying the products and services that the university offers, in an attempt to know its costs and efficiently manage the application of the resources financing the system (Alvarado, 2012). The SCAU model was never actually applied, but it gave IGAE very useful knowledge about the universities for developing the CANOA project (Contabilidad Analitica Normalizada de Organismos Autónomos) (Standardized Analytical Accounting model of Autonomous Bodies) in 1994. This project represented significant savings both in terms of its design and its maintenance.

When the CANOA project was published, various public universities were following it,and this facilitated the task of building a base model applicable to the different universities.

In the following years different initiatives emerged. In 2000, the University of Oviedo (Universidad de Oviedo) devised the ESCUDO (Estudio de Contabilidad Analitica para la Universidad de Oviedo) (Study of Analytical Accounting for the University of Oviedo) Model. This is a personalised analytical accounting model that refers to the CANOA project recommendations, but also establishes some particular aspects regarding accounting aggregates and allocation criteria.

During these years, various universities started to work with they own cost accounting systems. Generally, they were own models, more or less detailed, and aimed at being a decision-making tool rather than an instrument for providing information to users outside university management.

Interest for cost accounting in universities has increased in the last decade. In 2004 the "Documento sobre Principios Generales de Contabilidad Analitica en las Administraciones Públicas" (Document on the Main 
Principles of Analytical Accounting in Public Adninistrations) was published, which was compiled by IGAE itself, and in 2007 the Oficina de Cooperación Universitaria (OCU) (University Co-operation Office) published the Libro Blanco de los Costes en las Universidades (the White Book on Costs in Universities). It was aimed at improving university management by using tools for analytical accounting, budget control and management control, based on cost calculation.

However, perhaps the most decisive step that made cost accounting in universities a reality was the involvement in the CANOA project for public universities in Spain, by the Ministry of Education. This model is aimed at providing better knowledge of the real costs of the various activities in the universities and their relation with public and private financing. This model was approved in March 2011 and initially it was planned to be implemented for the academic year 2012-2013.

Implementing this model included a first period, when all the universities had to submit a personalisation document according to the approved model. After this presentation, the committee made up of the IGAE technicians had to issue a partial report on the suitability of the personalisation document. At the end of this stage, in November 2012, IGAE had received a total of 20 personalisation documents, representing $40 \%$ of the total of 50 public universities in Spain, and about 6 of the personalisation documents were validated by the General Intervention, and the corresponding comments were made on the rest. In view of the results, we can extrapolate that, despite the promising start to the personalisation tasks, seen in the results of the survey by the Efficiency, Effectiveness and Accountability committee, where 36 universities had already created the personalisation committee, these tasks have not prospered within the initially set terms.

It was in 2012 when cost accounting finally took priority among university management objectives, when the university prices were linked to the costs. Royal Decree 14/2012, of 20 April, on urgent measures for rationalising public spending on education, establishes that: "until all the universities implement analytical accounting systems and, at the most, until academic year 2015/2016"... in the "Degree Courses, public prices would cover between 15\% and 25\% of the costs in the first registration; between $30 \%$ and $40 \%$ of the costs in the second registration; and between $90 \%$ and $100 \%$ of the costs after the fourth registration."

As you can see, these terms would have required having the cost systems implemented for the economic year 2014, but, in reality, the universities were not yet ready. Therefore, in practice, the price has not been linked to the costs, as we still do not have transparent information on the costs. 


\section{The current status of implementing cost accounting in Spanish universities}

With a view to the previous section, the universities are finalising the implementation of their cost accounting systems. One of the best sources of information on the current status of cost accounting in Spanish universities is the survey "Contabilidad analitica en las universidades públicas españolas" (Analytical accounting in public universities in Spain), carried out by the "Management Section of CRUE" (CRUE is a non-profit association liasing between universities and the central government) in October 2014. In March 2016, when this article was closed, the data from the 2016 survey were not yet available.

The following results are derived from the 2014 survey (it must be remembered that the following percentages refer to the 34 universities that replied to the survey, and not to all Spanish universities).

- Implementing analytical accounting in Spanish universities in general: a total of $97 \%$ of the universities that responded to the survey (33 out of 34 responses) confirmed that, to a greater or lesser degree, they have started to develop cost accounting in their university.

- A total of $92 \%$ had appointed a work team for developing the project. These teams were made up mainly (74\%) of groups of less than 10 people, although 9 universities $(26 \%)$ expressed that their teams have between 10 and 19 people. Generally, these work teams are made up of staff from the management unit complemented by staff from IT or IT services, and very few universities have hired specific staff to carry out the development of the process, although 59\% of the universities have turned to specific external consulting to develop the project.

- In relation to the model or platform used to develop the project, 59\% express that they use OCU; $15 \%$ CANOA and the remaining 26\% state that they use other systems, probably their own systems designed internally for their university.

- Another interesting question is that the universities consider that the information obtained through cost accounting must be used mainly by the management and the governing bodies (between 70 and 97\%) for decision making. To a lesser degree (between 60 and 70\%) consider that governments must have access to the information (central government and autonomous governments) and, finally, about $40 \%$ to $50 \%$ consider that the community in general must have access to this information. These figures (see Table 1) indicate the universities' preference for using cost accounting for decision making, over transparency and third party information. 


\begin{tabular}{|l|r|r|}
\hline Units & No. of Universities and \% \\
\hline Management Team & 33 & $97 \%$ \\
\hline Social Council & 26 & $76 \%$ \\
\hline Other government bodies & 24 & $71 \%$ \\
\hline $\begin{array}{l}\text { Deans, Directors, Departments, etc. For the information on their area of } \\
\text { responsibility }\end{array}$ & 30 & $88 \%$ \\
\hline University Community & 18 & $53 \%$ \\
\hline Autonomous Community where their University is located & 21 & $71 \%$ \\
\hline Ministry & 22 & $65 \%$ \\
\hline Inspection and control bodies & 23 & $68 \%$ \\
\hline CRUE and the other universities & 18 & $53 \%$ \\
\hline General public & 14 & $41 \%$ \\
\hline
\end{tabular}

Table 1. Who should access the information obtained from cost accounting?

(Management Sector of CRUE, 2014)

\section{Cost accounting in the Catalan university system}

All public universities in Catalonia have started to implement a cost accounting system, and most of them have been applying their own model in recent years.

The particular feature of the Catalan model is that the universities report information to the "Secretaria d'Universitats $i$ Recerca de la Generalitat de Catalunya" (Universities and Research Secretariat of the Generalitat of Catalonia). This transfer of information must be within the framework of the UNEIX system, which has been in existence for more than 15 years. The Catalan university system (SUC) uses UNEIX, an advanced inter-university information system that integrates management data from twelve universities in Catalonia (public and private), and provides a follow-up of the needs, means and results. It is reliable, since the data are checked and validated before they are entered onto the system. At present, the UNEIX information system is coming close to the requirements of the CANOA model so that the SUC universities do not have to report cost information using two different models (the SUC model and the CANOA model).

In recent years, the cost systems in the universities in Catalonia, did not strictly follow the guidelines of the CANOA model. Some of the main differences were: a) greater practicality, great flexibility and less standardisation of the SUC model vis-à-vis the CANOA; b) the SUC model has a less specific aims than the CANOA model (for example, the Catalan universities determine the cost of their qualifications and the cost of the higher education system, but they are not interested in detailing the cost of one particular subject, as the CANOA model does; or, to mention just some differences; c) different distribution criteria for the PDI cost between the teaching and research activities, although it is true that both systems measure research based on outputs. 
These significant differences between the two models will be reduced, since the SUC-UNEIX model has started restructuring to try to converge with the CANOA model.

Below, we think it is interesting to identify the main characteristics of the cost accounting systems that have been applied in recent years in Catalan universities. The characteristics are grouped according to the objectives, the structure of the process, the development of the process (appointment, distribution and allocation stages) and, finally, according to the control indicators.

\subsection{Objectives}

We have asked the SUC universities about the strategic and legal objectives of cost accounting and on their preferential use of the information, essentially if they are pursuing information on cost centres or information on activities.

In relation to whether the objective of cost accounting focuses more on obtaining information for decision making (strategic question) or on fulfilling the transparency and accountability requirements (legal question), all the Catalan universities define cost accounting as a strategic question rather than a legal question. In fact, some universities consider that using cost accounting to calculate cost indicators in the Balanced Scorecard (BSC) is much more important than the commitment to transparency and accountability.

As for the type of information pursued, there is also a unanimous response, since all the universities propose calculating the costs per cost centre, essentially departments and teaching centres, and, in turn, calculating the cost for activities. In addition, they all identify three main activities: the teaching activity, research activity and the third mission activity.

\subsection{Structure}

We have analysed the structure of the analytical accounting system in Catalan universities. In particular, we have analysed the information source system; the cost system (discrete-live); the periodification between the academic year and the natural year; the type and classification of the cost; and, finally, the cost centres: 
- Source of the information: In most universities, the information that feeds the cost accounting comes from the budgetary accounting, and the financial accounting is only used to calculate the investment amortisations. However, some universities only use financial accounting to obtain the information for cost accounting.

- Cost system: As for the calculation period, generally it refers to discrete cost systems, where the costs are calculated once a period has finalised. However, some universities rely on a live analytical accounting system; i.e. with a continuous analysis system, where there is the possibility of real time calculations and analysis.

- Accrual/deferral: Neither is there any unanimity regarding cost periodification between the academic year and the natural year, which is an important consideration for determining the teaching costs of qualifications. Some universities apply accrual/deferral and others do not.

- Type and classification of the cost: The costs included in cost accounting are the staff costs, the costs of acquiring goods and services, the costs of external services, the financial costs and the amortisations, as well as the costs of current and capital transfers. System costs are not considered, or opportunity costs or the differences in inventories.

- Cost centres: the classification used to determine the different types of cost centres is, without a doubt, one of the areas where the universities differ the most. Some use classifications more in line with the CANOA model (main cost centre; auxiliary: directive, administrative and general; annex; mixed). Others differentiate between main cost centres (the teaching centres, as faculties and schools), main/auxiliary cost centres (the departments), and auxiliary cost centres. Other universities differentiate between main cost centres, support centres to the main centres and auxiliary cost centres.

\subsection{Process development: the distribution}

We have analysed the appointing and distributing process used in Catalan universities. In particular, we can highlight the two most significant elements in the whole university costs distribution process, the distribution of the teaching and research staff (PDI) costs and the methodology for distribution among cost centres. 
- Teaching and research staff (PDI) costs: The consideration between the teaching activity and the research activity for the staff costs is, obviously, the most significant element of the distribution process, both because of its quantitative (the staff costs are the greatest outlay for universities) and qualitative significance (identifying which part of the costs is teaching cost and which part is research cost). This means going to the essence of the university activity and measuring the dedication of its teaching and research staff (Saladrigues et al., 2014)-. Each model in each university has its own particular features. However, in general terms, we can confirm the following:

- most universities distribute between activities according to the internal plans of academic dedication (or dedication plans or commitments). In other words, according to personalised teaching loads depending on the research activity performed by the teaching and research staff. This distribution differs from that set out in the CANOA model (rule 23-;

- where some universities choose to distribute the teaching and research staff costs between activities at department level, and others prefer individualised distribution (at each teaching and research staff level).

- Waterfall distribution / distribution at the same level between cost centres: Generally, the distribution between cost centres is done at the same level, although some universities apply waterfall distribution.

\subsection{Process development: allocation}

We have analysed the process of allocating the costs of the cost centres (departments, faculties...) to the activities or outputs that the universities offer: teaching, research and third mission. We mention the main aspects of the allocation of the two main activities.

- Allocation to teaching activity: All universities distribute the teaching activity costs to the official qualifications, both at degree and master level. The measuring unit for qualification allocation are the teaching hours given by each department to each qualification, and the enrolled credits. This way, the official qualification (degree and master) makes up the most disaggregated teaching activity, and the costs per subject are not calculated, as envisaged in the CANOA model. 
- Allocation to research activity: Given the complexity of this process, the SUC universities establish a first level of global analysis (general research costs). At a second level, some universities allocate the research costs to research lines or groups, while others allocate it to research projects.

\subsection{Control indicators}

Finally, we have analysed the different indicators that Catalan universities use. Generally, we can confirm that, to a large degree, the SUC universities use the same indicators, considering both cost centre indicators (auxiliary centres, departments, teaching centres); activity indicators (teaching activity, distinguishing qualifications, research activity); and contribution margins.

The differences observed between the SUC universities lie in the type and degree of analysis and in the degree to which the respective governing bodies use the analysis, rather than in its own classification and definition.

\section{Conclusions}

In this article we have analysed the development, implementation and use of the cost accounting systems that the universities are adopting. After justifying the need for universities to have a cost accounting system, the developments that have taken place in the last 25 years are discussed. Subsequently, an analysis is made of the current status of cost accounting in Spanish universities, which is built up around the CANOA model, and the characteristics of the cost accounting in the universities in the Catalan university system (SUC) are detailed.

The main differences between the CANOA model and the SUC model lie in the fact that the SUC model has greater flexibility and less standardisations; the SUC objectives are more general; and the distribution criteria of the teaching and research staff cost among the teaching and research activities are different.

These differences between the two models will start to reduce in forthcoming years, as cost accounting in universities is consolidated and the SUC-UNEIX model tends to converge with the CANOA model. 


\section{References}

Alvarado Riquelme, M. (2012). La utilidad de las hojas de tiempo como instrumento para medir la eficiencia promocional del sistema universitario público español. (Using time sheets as a tool for measuring the promotional efficiency of the public university system in Spain). Revista Internacional de Economia y Gestión de las organizaciones, 1(2), 129-156.

Araujo, P. (2003). Nuevo institucionalismo, teoría de la estructuración y cambio en los sistemas y prácticas de contabilidad de gestión. (New institutionalism, theory of the structurising and change in the systems and practices of management accounting). Revista Española de Financiación y Contabilidad: Teorias y métodos de investigación, XXXII(118), 693-724.

Atkinson, A.A. et al. (1997). New directions in management accounting research. Journal of Management Accounting Research, 9, 79-109.

Ball, R., \& Halwachi, J. (1987). Performance Indicators in Higher Education. Higher Education, 16, 393-405. https://doi.org/10.1007/BF00129112

Bergevärn, L.E. et al. (1995). Institutionalization of municipal accounting: A comparative study between Sweden and Norway. Scandinavian Journal of Management, 11(1), 25-41. https://doi.org/10.1016/0956-5221(94)00024-C

CVCP. Committee of Vice-Chancellors and Principals (1985). Report of the Steering Committee for Efficiency Studies in Universities (The Jarratt Report).

CVCP. Committee of Vice-Chancellors and Principals (1988). The Costing of Research and Projects in Universities: A Report and Guidance for Universities.

Estermann, T. et al. (2013). Financially Sustainable Universities. Full Costing: Progress and Practice. European University Association.

Kells, H.R. (1991). The Inadequacy of Performance Indicators for Higher Education: The Need for a More Comprehensive and Development Construct. Higher Education Management, 2(3), 258-270.

Meyer, J.W., \& Rowan, B. (1997). Institutionalized organizations: Formal structures as myth and ceremony. American Journal of Sociology, 83(2), 310-363.

Obester, B. (2001). Cost Accounting Standards in Higher Education: Impact Of Required Changes. Journal of Applied Business Research, 17(3), 79-86. 
Saladrigues, R. et al. (2014). Contabilidad Analítica de las Universidades: Los costes de personal y la identificación de la actividad docente y de investigación. Trabajo presentado en las II Jornadas sobre implantación de la Contabilidad analítica en las universidades españolas. (Analytical Accounting in Universities: The costs of staff and identifying the teaching and research activity. Work submitted in the II Workshops on implementing analytical accounting in Spanish universities) U. de Valencia.

Sectorial de Gerentes de la CRUE (2014). Contabilidad analítica en las Universidades Públicas Españolas. (Analytical accounting in Public Universities in Spain).

\section{Versión en español}

Título: La contabilidad de costes de la universidad española y catalana: Estado actual de su implantación

\section{Resumen}

Objeto: El principal objetivo de este trabajo es analizar el desarrollo, implementación y uso de los distintos sistemas de costes en las universidades.

Diseño/metodología/enfoque: En primer lugar se justifica la necesidad de disponer de un sistema de costes y se identifican los principales elementos que favorecen que el proceso de implantación de un sistema de costes se haya llevado a cabo.

Posteriormente, a través de la revisión de la literatura, de encuestas de diversos organismos y de entrevistas a los responsables de la gestión de los costes de las universidades, se constata el grado de implantación de la contabilidad de costes en las universidades públicas, y si existe homogeneidad o no entre los diferentes sistemas de costes.

Aportaciones y resultados: Se evidencia la disparidad de sistemas y se identifican elementos que pueden contribuir tanto a mejorar el conocimiento de la contabilidad de costes de las instituciones de enseñanza superior como para conseguir un mayor grado de aproximación entre los diferentes sistemas de costes. 
Limitaciones: El proceso de implantación de los sistemas de costes en las universidades no ha finalizado. Debe tenerse en cuenta que el análisis se realiza, pues, en pleno proceso de implantación.

Implicaciones prácticas: Los resultados obtenidos son interesantes para los profesionales de la gestión universitaria, así como para los usuarios de la información. Además, contribuirán a la mejora de la eficiencia de los recursos públicos.

Originalidad / Valor añadido: Este artículo aporta información actual y oportuna sobre una nueva herramienta que contribuirá a mejorar la gestión universitaria.

Palabras clave: Contabilidad de costes, Costes universitarios, Costes docentes, Costes de investigación Códigos JEL: M41, H52, I23

\section{Contabilidad de costes y Universidades}

En el escenario actual en el que está inmerso la universidad pública -y también la privada- en el que, cada vez más, las universidades compiten en un entorno internacional en la captación de talento en investigación y en docencia; en el que compiten en la búsqueda de una buena posición en los ránquines universitarios; en el que se exige un alto grado de transparencia y de rendición de cuentas; y en el que los recursos se han reducido muy significativamente, la mejora de la eficiencia se ha convertido en uno de los principales objetivos de las universidades.

La mejora de la eficiencia requiere, entre otros,

- información de los costes e ingresos de las unidades y centros de coste universitarios;

- análisis de los costes e ingresos por actividades -no solamente por unidades y centros- y;

- indicadores que midan la eficiencia de las distintas actividades que desarrollan las universidades (docencia, investigación, transferencia tecnológica y tercera misión y extensión universitaria). 
Es en ese contexto que la contabilidad de costes se convierte en un instrumento imprescindible para las universidades, lo que explica los esfuerzos que en los últimos años se están destinando a la implantación de sistemas de análisis de costes en la universidad (Estermann et al., 2013).

El proceso de implantación del análisis de los costes de las universidades se ha acelerado en los últimos años. Los dos factores más determinantes del avance de la contabilidad analítica en las universidades han sido, en primer lugar, el desarrollo de un Modelo de Contabilidad Analítica para las Universidades Públicas Españolas: el modelo de Contabilidad Analítica Normalizada de Organismos Autónomos (CANOA, 2011). Y en segundo lugar, el Real Decreto 14/2012, de 20 de abril de racionalización del gasto público en el gasto educativo, al objeto de conocer el coste real de las titulaciones para la determinación de los precios públicos, fijando el límite de cumplimiento legal hasta el curso universitario 2015/16.

Otros factores que han contribuido a la implantación de la contabilidad de costes en las universidades han sido los avances en el Sistema Integrado de Información Universitario (SIIU) y el ya consolidado UNEIX para el caso de Catalunya, y la concienciación de que la contabilidad analítica adquiere relevancia para la toma de decisiones.

\section{Aportación de la contabilidad de costes y de los indicadores}

Uno de los principales objetivos de la contabilidad de costes es obtener la información adecuada que permita mejorar la eficiencia de una organización. La contabilidad de gestión se erige, pues, como una valiosa herramienta que permite planificar, controlar y tomar decisiones de forma más eficiente.

La implantación de sistemas de contabilidad de gestión requiere, como paso previo, el establecimiento de modelos de costes, de manera que posibiliten la determinación de sus costes, de sus ingresos y de los niveles de cobertura de los mismos, además de potenciar el análisis de cuestiones fundamentales para su gestión.

En un entorno de transformaciones constantes como las que se producen en el contexto actual, las universidades deben adaptarse a los cambios que se están produciendo a su alrededor (Bergevärn et al., 1995; Meyer \& Rowan, 1997). Estos cambios, tanto en el entorno como en las estructuras de una organización, implican cambios en las necesidades de información. En consecuencia, el modo en que se 
utiliza la información para medir y motivar el rendimiento o para la toma de decisiones también debe adaptarse a las nuevas circunstancias (Atkinson et al., 1997; Araujo 2003).

En este proceso, el sistema de contabilidad y control de gestión tienen un destacado papel que jugar principalmente en dos aspectos:

- La gerencia puede utilizar el potencial informativo del sistema de contabilidad y control de gestión para acometer los cambios que permitan ajustar la organización a la nueva situación.

- El propio sistema de contabilidad y control de gestión puede cambiar para adaptarse a las nuevas condiciones.

Además, para que el sistema de control pueda hacer un seguimiento continuo de la evolución de la organización, se requiere del uso de indicadores. Es necesario, pues, la identificación y elección de aquellos indicadores de control que mejor permitan controlar la evolución de la universidad y de los diferentes centros docentes, departamentos y unidades. Estos indicadores pueden tanto orientar "a priori" el comportamiento de la universidad, como evaluar "a posteriori", de forma cuantitativa, la eficacia de la gestión de cada responsable y de cada centro de coste o unidad organizativa.

De esta manera los indicadores de control pueden ser utilizados para:

- Establecer los objetivos iniciales hacia los que deben orientarse las diferentes unidades organizativas, $y$

- Evaluar a posteriori la actuación (del responsable) de cada centro docente y de cada departamento o unidad organizativa.

En términos generales, estos indicadores no son más que "medidas objetivas, usualmente cuantitativas, de los logros de una institución" o bien de todo un sistema, como, por ejemplo, de un sistema de educación superior” (Ball \& Halwachi, 1987). Aplicados al ámbito universitario, los indicadores miden ciertos aspectos de los inputs de las universidades, de su funcionamiento y de sus resultados (Kells, 1991).

Una vez alcanzado un consenso en el número y definición de los indicadores, una de sus principales ventajas reside en su objetividad y su fácil interpretación individualizada. La principal dificultad, sin embargo, se presenta al intentar obtener una visión global del rendimiento de las unidades evaluadas. 
Desafortunadamente, la identificación de indicadores que midan los outputs de las universidades es de una enorme dificultad, tanto en docencia, como en investigación y tercera misión.

Lo mismo sucede con la identificación de los inputs, dada la peculiaridad de los procesos de producción en la universidad, puesto que en la enseñanza superior se realizan de forma simultánea actividades de distinta naturaleza. Así, la mayoría de los recursos empleados son compartidos por las dos actividades, cuestión que condiciona todo el proceso de evaluación de su actividad. Quizás el mejor ejemplo lo constituyan los costes laborales del profesorado docente e investigador (PDI), puesto que estos costes se destinan a todas las actividades de la universidad (docencia, investigación y tercera misión).

Finalmente, además de las dificultades expuestas en los párrafos anteriores, tenemos la complejidad añadida del retorno de la investigación en la docencia y, en general, de las relaciones inevitables que se generan entre ambas actividades: las universidades generan conocimiento a través de la investigación, con lo que la investigación revierte en la docencia y, por otro lado, las universidades difunden sus conocimientos a través de la labor docente.

\section{Los inicios de la contabilidad de costes en las universidades}

La presencia de la contabilidad de costes en las universidades es relativamente reciente. De hecho, ésta era casi inexistente hasta mediados de los años 80, cuando se establece el comité CVCP (Committee of Vice-Chancellors and Principals), formado por la mayoría de universidades del Reino Unido, para llevar a cabo una serie de estudios sobre la eficiencia en la gestión de las universidades. Este comité concluye su trabajo en el año 1985 con la publicación del informe: Report of the Steering Committee for Efficiency Studies in Universities - el denominado Informe Jarrat-. El Informe Jarrat resalta principalmente la falta de sistemas de contabilidad de gestión en las universidades y la necesidad de estas instituciones de mejorar en sus mecanismos de información, de tal forma que puedan conocer cuál es el coste de los diferentes centros que las componen y conseguir así una mayor responsabilidad en la gestión y el control de los mismos. Quizás el aspecto más destacable de este informe sea que define una serie de indicadores de rendimiento que pretenden ser un instrumento de gestión, en lugar de ser sólo un mero instrumento de rendición de cuentas.

A partir de la publicación de este informe aparece una primera respuesta: la creación de un nuevo grupo de trabajo en el año 1988 (CVCP, 1988) que se encargará de redactar una directrices para determinar el coste total de la investigación, así como el coste de otras actividades financiadas por 
subvenciones públicas e incluso proyectos financiados por fuentes externas. Este grupo de trabajo pone énfasis en conocer cuál es el coste total de todas las actividades llevadas a cabo en las universidades, ya sean financiadas de forma pública o externa. Además, establece la recomendación de que las universidades adopten sistemas de costes completos basándose en metodologías coherentes con los principios ya aceptados en la industria y en otros centros de gobierno.

El desarrollo de la contabilidad de costes en los Estados Unidos siguió un cauce diferente al británico, aunque paralelo en el tiempo. Mientras los informes del CVCP surgían en el Reino Unido, en Estados Unidos la Oficina de Presupuestos y Gestión (OMB) proporcionaba una guía para proceder a la contabilidad de costes en las instituciones de educación superior. Anteriormente la relación entre las universidades y el Gobierno Federal se basaba en la mutua confianza y respeto. Sin embargo, es a partir de 1995 (Obester, 2001) cuando las universidades que reciben más de 25 millones de dólares en subvenciones federales, o bien las que se incluyen en las 99 principales instituciones de investigación, son obligadas a seguir 4 de las 19 normas CAS establecidas por la Oficina de Gestión y Presupuestos (A-21) sobre contabilidad de costes. Las normas CAS (Cost Accounting Standards) tratan sobre los procedimientos de contabilidad de costes y su divulgación. Las cuatro normas que debían seguir las universidades mencionadas son las siguientes:

- Norma CAS 501; coherencia en la estimación, la acumulación y la presentación de informes de costes.

- Norma CAS 502; la coherencia en la localización de coste incurrido para el mismo propósito.

- Norma CAS 505; no contabilizar aquellos costes no admisibles.

- Norma CAS 506; coherencia en los períodos de contabilidad de costes.

Hasta la incorporación de estas normas era posible utilizar una contabilidad de costes separada entre costos directos e indirectos. Sin embargo, a partir de este momento las universidades se ven obligadas a medir, acumular, asignar y distribuir todo tipo de costes - y no sólo los costes directos respecto a un determinado contrato o proyecto-. La contabilidad de costes empezaba a considerar todas las actividades propias de la universidad.

En el estado español, la preocupación para el cálculo de costes en las universidades surge también a partir de los años 90, impulsada por la Intervención General de la Administración del Estado (IGAE). Sin embargo, como veremos, el proceso de implantación ha sido mucho más lento. 
Inicialmente afloraron proyectos como el modelo SCAU (Sistema de Contabilidad Analítica para Universidades, 1991), que nació con la finalidad de obtener información que permitiese identificar los productos y servicios que ofrece la universidad para tratar de conocer sus costes y gestionar eficientemente la aplicación de los recursos que financian el sistema (Alvarado, 2012). El modelo SCAU nunca llegó a aplicarse, pero aportó a la IGAE un conocimiento de las universidades de gran utilidad para el desarrollo del proyecto CANOA (Contabilidad Analítica Normalizada de Organismos Autónomos) en el año 1994. Este proyecto suponía un importante ahorro de medios tanto desde el punto de vista de su diseño como de su mantenimiento.

En el momento de la publicación del proyecto CANOA estaban adheridas al mismo varias universidades públicas, lo que facilitó que se constituyera un modelo base de aplicación a las distintas universidades.

En los años siguientes surgieron diversas iniciativas. En el año 2000, la Universidad de Oviedo elabora el Modelo ESCUDO (Estudio de Contabilidad Analítica para la Universidad de Oviedo). Se trata de un modelo personalizado de contabilidad analítica que toma como referencia las recomendaciones del proyecto CANOA, pero establece unas particularizaciones en cuanto a agregados contables y criterios de imputación.

Durante estos años, diversas universidades empiezan a trabajar con sistemas de contabilidad de costes propios. En general se trata de modelos propios, más o menos elaborados, y con objeto de ser un instrumento para la toma de decisiones más que con el objeto de proporcionar información a usuarios ajenos a la gestión de la universidad.

El interés por la contabilidad de costes en las universidades va en aumento en la última década. En el 2004 se publica el "Documento sobre Principios Generales de Contabilidad Analítica en las Administraciones Públicas" elaborado por la misma IGAE y en el 2007 la Oficina de Cooperación Universitaria (OCU) publica el Libro Blanco de los Costes en las Universidades. Su propósito era mejorar la gestión universitaria a través del uso de herramientas de contabilidad analítica, control presupuestario y control de gestión, basándose en el cálculo de costes.

No obstante, quizás el paso más determinante para que la contabilidad de costes de las universidades sea una realidad se ha dado con la particularización del proyecto CANOA para las universidades públicas españolas por parte del Ministerio de Educación. El objetivo de este modelo es permitir un mejor conocimiento de los costes reales de las diferentes actividades de las universidades y su relación 
con la financiación pública y privada. Este modelo fue aprobado en marzo de 2011 y su implantación estaba prevista, inicialmente, para el curso académico 2012-2013.

La implementación de este modelo comprendía un primer período, en el que todas las universidades debían presentar un documento de personalización de acuerdo con el modelo aprobado. Tras dicha presentación, la comisión formada por los técnicos de la IGAE debería emitir un informe parcial sobre la adecuación del documento de personalización. Finalizado este período, en noviembre de 2012, se habían recibido por parte de la IGAE un total de 20 documentos de personalización, lo que representa un $40 \%$ sobre un conjunto de 50 universidades públicas españolas, de los cuales fueron validados por la Intervención General un total de 6 documentos de personalización, habiéndose efectuado los reparos correspondientes sobre los restantes. A la vista de los resultados, podemos extrapolar que, a pesar de unos inicios prometedores de los trabajos de personalización, plasmados en los resultados de la encuesta de la comisión de Eficiencia, Eficacia y Rendición de Cuentas, donde 36 universidades tenían ya creado el comité de personalización, estos trabajos no han prosperado en los plazos inicialmente fijados.

Será en 2012 cuando definitivamente la contabilidad de costes adquiere prioridad entre los objetivos de la gestión universitaria, cuando se vinculan los precios universitarios a los costes. El Real Decreto Ley 14/2012, de 20 de abril, de medidas urgentes de racionalización del gasto público en el ámbito educativo, establece que: "hasta que todas las universidades implanten sistemas de contabilidad analítica y, como máximo, hasta el curso universitario 2015/2016”... en las "Enseñanzas de Grado, los precios públicos cubrirán entre el 15\% y el 25\% de los costes en primera matrícula; entre el 30\% y el 40\% de los costes en segunda matrícula; y entre el 90\% y el 100\% de los costes a partir de la cuarta matrícula."

Como puede apreciarse, estos plazos hubieran requerido tener implantados los sistemas de costes para el ejercicio económico de 2014, cuando, en realidad, las universidades no estaban aún preparadas. En la práctica, pues, la vinculación del precio a los costes no se ha producido, al no disponer aún de una información transparente sobre los costes. 


\section{El estado actual de implantación de la contabilidad de costes en las universidades españolas}

Atendiendo a lo presentado en el apartado anterior, las universidades están ultimando la implantación de sus sistemas de contabilidad de costes. Una de las mejores fuentes de información acerca de la situación actual de la contabilidad de costes en las universidades españolas son las encuestas "Contabilidad analítica en las universidades públicas españolas", realizadas por la "Sectorial de Gerentes de la CRUE" en octubre de 2014 y en marzo de 2016 - en el momento de cerrar este artículo, los datos de la encuesta de 2016 no están aún disponibles-.

De la encuesta de 2014 se derivan los siguientes resultados (debe tenerse en cuenta que los porcentajes que siguen se refieren a las 34 universidades que respondieron la encuesta, y no al total de las universidades españolas).

- La implantación de la contabilidad analítica en las universidades españolas es general. El 97\% de las universidades que respondieron la encuesta (33 de 34 respuestas) afirman que, en mayor o menor medida, han comenzado a desarrollar la contabilidad de costes en su universidad.

- El 92\% había designado un equipo de trabajo para el desarrollo del proyecto. Estos equipos estaban formados mayoritariamente (74\%) por grupos de menos de 10 personas, aunque 9 universidades (26\%) manifestaron que sus equipos son de 10 a 19 personas. En general, estos equipos de trabajo están compuestos por el personal de la unidad de gerencia y se complementan con personal del servicio de informática o bien de tecnologías de la información, y muy pocas universidades han contratado personal específico para llevar a cabo el desarrollo del proceso, aunque el 59\% de las universidades han contado con asesoría externa específica para desarrollar el proyecto.

- En relación al modelo o plataforma utilizada para desarrollar el proyecto, el 59\% manifiestan utilizar OCU; el 15\% CANOA y el 26\% restante manifiesta utilizar otros sistemas, probablemente sistemas propios diseñados internamente para su universidad.

- Otra cuestión interesante es que las universidades consideran que la información obtenida a través de la contabilidad de coste debe ser utilizada mayoritariamente por la dirección y los órganos de gobierno (entre el 70 y el 97\%) para la toma de decisiones. En menor medida (entre el 60 y el 70\%) consideran que deben tener acceso a la información los gobiernos (gobierno central y gobiernos autonómicos) y, finalmente, alrededor del $40 \%$ al $50 \%$ consideran que la 
comunidad en general debe tener acceso a dicha información. Estas cifras (véase la tabla 1) denotan la preferencia de las universidades por la utilidad de la contabilidad de costes en el ámbito de la toma de decisiones, por encima del ámbito de la transparencia y la información a terceros.

\begin{tabular}{|l|r|r|}
\hline Unidades & Núm. Universidades y \% \\
\hline Equipo de dirección & 33 & $97 \%$ \\
\hline Consejo Social & 26 & $76 \%$ \\
\hline Otros órganos del gobierno & 24 & $71 \%$ \\
\hline $\begin{array}{l}\text { Decanos, Directores, Departamento, etc. Para la información de su área de } \\
\text { responsabilidad }\end{array}$ & 30 & $88 \%$ \\
\hline Comunidad Universitaria & 18 & $53 \%$ \\
\hline Comunidad Autónoma en la que se ubica su Universidad & 21 & $71 \%$ \\
\hline Ministerio & 22 & $65 \%$ \\
\hline Órganos de fiscalización & 23 & $68 \%$ \\
\hline CRUE y resto universidades & 18 & $53 \%$ \\
\hline Público en general & 14 & $41 \%$ \\
\hline
\end{tabular}

Tabla 1. ¿Quién debe acceder a la información que se obtiene de la contabilidad de costes? (Sectorial de Gerentes de la CRUE, 2014)

\section{La contabilidad de costes en el sistema universitario catalán}

Todas las universidades públicas catalanas han iniciado la implementación de un sistema de contabilidad de costes, y la mayoría ya ha venido aplicando un modelo propio en los últimos años.

La particularidad del modelo catalán reside en que las universidades reportan información a la "Secretaria d'Universitats $i$ Recerca de la Generalitat de Catalunya". Esta transferencia de información debe enmarcarse en el marco del sistema UNEIX, con más de 15 años de existencia. El sistema universitario catalán (SUC) cuenta con UNEIX, un avanzado sistema de información interuniversitario que integra datos de gestión de doce universidades de Catalunya (públicas y privadas) y que permite hacer un seguimiento de las necesidades, medios y resultados. Se trata de un sistema fiable, pues los datos son revisados y validados antes de su introducción. Actualmente el sistema de información UNEIX se está acercando a los requerimientos del modelo CANOA al objeto que las universidades del SUC no deban reportar información de costes con dos modelos diferentes (modelo del SUC y modelo CANOA).

En estos últimos años, los sistemas de costes de las universidades en Catalunya, no seguían estrictamente las directrices del modelo CANOA. Algunas de las principales diferencias serían: 
- una mayor practicidad, mayor flexibilidad y menor normalización del modelo SUC frente al CANOA;

- unos objetivos más generalistas del modelo SUC frente al CANOA (por ejemplo, las universidades catalanas determinan el coste de sus titulaciones y el coste del sistema de enseñanza superior, pero no se interesan por el detalle del coste de una asignatura en concreto, como sí determina el modelo CANOA; o, por citar solo algunas diferencias,

- unos criterios de distribución distintos del coste del PDI entre las actividades de docencia e investigación, aunque bien es cierto que ambos sistemas miden la investigación en base a outputs.

Estas importantes diferencias entre los dos modelos se irán reduciendo, puesto que el modelo SUCUNEIX ha iniciado una reestructuración para tender a converger con el modelo CANOA.

En lo que sigue, consideramos interesante identificar las principales características de los sistemas de contabilidad de costes que se han venido aplicando en los últimos años en las universidades catalanas. Las características se agrupan en relación a los objetivos, a la estructura del proceso, al desarrollo del proceso (fases de asignación, reparto e imputación) y, finalmente, a los indicadores de control.

\subsection{Objetivos}

Hemos preguntado a las universidades del SUC sobre los objetivos estratégicos y legales de la contabilidad de costes y sobre la preferencia de la información, fundamentalmente si lo que se persigue es información de centros de coste o información de las actividades.

En relación a si el objetivo de la contabilidad de costes se centra más en la obtención de información para la toma de decisiones (cuestión estratégica) o en el cumplimiento de los requisitos de trasparencia y rendición de cuentas (cuestión legal), todas las universidades catalanas definen la contabilidad de costes como una cuestión estratégica más que una cuestión legal. De hecho, algunas universidades consideran que la utilidad de la contabilidad de costes para el cálculo de indicadores de costes en el Cuadro de Comando Integral (CCI) está muy por encima del compromiso de transparencia y rendición de cuentas.

En lo que se refiere al tipo de información perseguido existe también unanimidad, puesto que todas las universidades se proponen calcular el coste por centros de coste -fundamentalmente departamentos y 
centros docentes- y, a su vez, calcular el coste por actividades. Todas, además, identifican tres actividades principales: la actividad docente, la actividad de investigación y la actividad de tercera misión.

\subsection{Estructura}

Hemos analizado la estructura del sistema de contabilidad analítica de las universidades catalanas. En particular, se ha analizado el sistema de origen de la información; el sistema de costes (discreto-vivo); la periodificación entre el año académico y el año natural; la tipología y la clasificación del coste; y, finalmente, los centros de coste:

- Origen de la información: En la mayoría de universidades, la información que nutre la contabilidad de costes surge de la contabilidad presupuestaria, y solamente se utiliza la contabilidad financiera para el cálculo de las amortizaciones de las inversiones. No obstante, algunas universidades utilizan exclusivamente la contabilidad financiera para obtener la información para la contabilidad de costes.

- Sistema de costes: En lo que se refiere al período de cálculo, en general se trata de sistemas de costes discretos, donde se calculan los costes una vez finalizado un período. Sin embargo, algunas universidades cuentan con un sistema vivo de contabilidad analítica - es decir, con un sistema de análisis continuo- donde existe la posibilidad de cálculo y análisis en tiempo real.

- Periodificación: Tampoco existe unanimidad en el tratamiento de la periodificación de los costes entre el año académico y el año natural, una cuestión relevante para la determinación de los costes docentes de las titulaciones. Hay universidades que periodifican y otras que no.

- Tipología y clasificación del coste: Los costes que se recogen en la contabilidad de costes son los de personal, los de adquisición de bienes y servicios, los de servicios exteriores, los costes financieros y las amortizaciones, así como los costes de transferencias corrientes y de transferencias de capital. No se consideran costes del sistema ni los costes de oportunidad ni las diferencias de inventarios.

- Los centros de coste: la clasificación utilizada para determinar los diferentes tipos de centros de costes es, sin duda, uno de los aspectos en que más difieren las universidades. Algunas utilizan clasificaciones más acordes con el modelo CANOA (centro de coste principal; auxiliar: 
directivo, administrativo y general; anexo; mixto). Otras clasifican entre centros de costes principales (los centros docentes, como facultades y escuelas), centros de costes principales/auxiliares (los departamentos), y centros de costes auxiliares. Otras universidades clasifican entre centros de costes principales, centros de soporte a los centros principales y centros de costes auxiliares.

\subsection{Desarrollo del proceso: El reparto}

Hemos analizado el proceso de asignación y de reparto de las universidades catalanas. En particular, destacamos los dos elementos más relevantes de todo proceso de reparto de los costes universitarios, el reparto de los costes del PDI y la metodología del reparto entre centros de coste.

- Costes del PDI: La consideración entre la actividad de docencia y la actividad de investigación de los costes de personal del PDI es, sin duda, el elemento más relevante del proceso de reparto, tanto por su importancia cuantitativa - los costes de personal son el mayor de los costes de las universidades- como cualitativa - identificar que parte de los costes es coste docente y que parte es coste de la investigación, es ir a la esencia de la actividad de la universidad y de la medida de la dedicación de su personal docente e investigador (Saladrigues et al, 2014)-. Cada modelo de cada universidad tiene sus particularidades. Sin embargo, en términos generales puede afirmarse lo siguiente:

- la mayoría de universidades distribuye entre actividades atendiendo a los planes internos de dedicación académica (o planes o compromisos de dedicación), es decir, de acuerdo con cargas docentes personalizadas en función de la actividad investigadora que realiza el PDI. Este reparto difiere del establecido en el modelo CANOA -norma 23-; y

- unas universidades optan por repartir el coste del PDI entre actividades a nivel de departamentos, mientras que otras optan por un reparto individualizado (a nivel de cada PDI).

- Reparto en cascada / reparto al mismo nivel entre centros de coste: en general los repartos entre centros de coste se producen a un mismo nivel, aunque algunas universidades realizan el reparto en cascada. 


\subsection{Desarrollo del proceso: imputación}

Hemos analizado el proceso de imputación de los costes de los centros de costes (departamentos, facultades...) a las actividades u outputs que ofrecen las universidades: docencia, investigación y tercera misión. Mencionamos los principales aspectos de la imputación a las dos actividades principales.

- Imputación a la actividad docente: Toda las universidades distribuyen los costes de actividad docente a las titulaciones oficiales, tanto de grado como de máster. La unidad de medida para la imputación a las titulaciones son las horas docentes impartidas por cada departamento a cada titulación, y los créditos matriculados. De esta forma, la titulación oficial (grado y máster) constituye la actividad docente más desagregada, y no se llega a calcular el coste por asignatura, tal y como está previsto en el modelo CANOA.

- Imputación a la actividad de investigación: Dada la complejidad de este proceso, las universidades del SUC establecen un primer nivel de análisis de manera global (costes generales de investigación). En un segundo nivel, algunas universidades imputan los costes de investigación a líneas o grupos de investigación, mientras otras lo hacen a proyectos de investigación.

\subsection{Indicadores de control}

Finalmente, hemos realizado un análisis de los diferentes indicadores que utilizan las universidades catalanas. En general podemos afirmar que las universidades del SUC utilizan, en gran medida, los mismos indicadores, considerando tanto indicadores de centro de costes (centros auxiliares, departamentos, centros docentes); indicadores de actividades (actividad de docencia -distinguiendo titulaciones-, actividad de investigación); y márgenes de cobertura.

Las diferencias observadas entre las universidades del SUC se sitúan en el tipo y grado de análisis y en el grado de utilización que hacen los respectivos órganos de gobierno, más que en su propia clasificación y definición. 


\section{Conclusiones}

En este artículo hemos analizado el desarrollo, la implementación y el uso de los sistemas de costes que las universidades están adoptando. Después de justificar la necesidad de que las universidades tengan un sistema de contabilidad de costes, se han presentado los avances que se han producido en los últimos 25 años. Posteriormente, se ha analizado el estado actual de implantación de la contabilidad de costes en las universidades españolas, que se configura alrededor del modelo CANOA, y se han detallado las características de las contabilidades de costes de las universidades del sistema universitario catalán (SUC).

Las principales diferencias entre el modelo CANOA y el modelo del SUC residen en que el modelo del SUC tiene una mayor flexibilidad y menor normalización; los objetivos del SUC son más generalistas; y los criterios de distribución del coste del PDI entre las actividades de docencia e investigación difieren.

Estas diferencias entre los dos modelos tenderán a reducirse en los próximos años, a medida que la contabilidad de costes en las universidades se vaya consolidando y que el modelo SUC-UNEIX tienda a converger con el modelo CANOA.

\section{Referencias}

Alvarado Riquelme, M. (2012). La utilidad de las hojas de tiempo como instrumento para medir la eficiencia promocional del sistema universitario público español. (Using time sheets as a tool for measuring the promotional efficiency of the public university system in Spain). Revista Internacional de Economia y Gestión de las organizaciones, 1(2), 129-156.

Araujo, P. (2003). Nuevo institucionalismo, teoría de la estructuración y cambio en los sistemas y prácticas de contabilidad de gestión. (New institutionalism, theory of the structurising and change in the systems and practices of management accounting). Revista Española de Financiación y Contabilidad: Teorías y métodos de investigación, XXXII(118), 693-724.

Atkinson, A.A. et al. (1997). New directions in management accounting research. Journal of Management Accounting Research, 9, 79-109.

Ball, R., \& Halwachi, J. (1987). Performance Indicators in Higher Education. Higher Education, 16, 393-405. https://doi.org/10.1007/BF00129112 
Bergevärn, L.E. et al. (1995). Institutionalization of municipal accounting: A comparative study between Sweden and Norway. Scandinavian Journal of Management, 11(1), 25-41. https://doi.org/10.1016/0956-5221(94)00024-C

CVCP. Committee of Vice-Chancellors and Principals (1985). Report of the Steering Committee for Efficiency Studies in Universities (The Jarratt Report).

CVCP. Committee of Vice-Chancellors and Principals (1988). The Costing of Research and Projects in Universities: A Report and Guidance for Universities.

Estermann, T. et al. (2013). Financially Sustainable Universities. Full Costing: Progress and Practice. European University Association.

Kells, H.R. (1991). The Inadequacy of Performance Indicators for Higher Education: The Need for a More Comprehensive and Development Construct. Higher Education Management, 2(3), 258-270.

Meyer, J.W., \& Rowan, B. (1997). Institutionalized organizations: Formal structures as myth and ceremony. American Journal of Sociology, 83(2), 310-363.

Obester, B. (2001). Cost Accounting Standards in Higher Education: Impact Of Required Changes. Journal of Applied Business Research, 17(3), 79-86.

Saladrigues, R. et al. (2014). Contabilidad Analítica de las Universidades: Los costes de personal y la identificación de la actividad docente y de investigación. Trabajo presentado en las II Jornadas sobre implantación de la Contabilidad analítica en las universidades españolas. (Analytical Accounting in Universities: The costs of staff and identifying the teaching and research activity. Work submitted in the II Workshops on implementing analytical accounting in Spanish universities) U. de Valencia.

Sectorial de Gerentes de la CRUE (2014). Contabilidad analítica en las Universidades Públicas Españolas. (Analytical accounting in Public Universities in Spain).

Intangible Capital, 2017 (www.intangiblecapital.org)

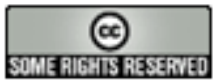

Article's contents are provided on an Attribution-Non Commercial 3.0 Creative commons license. Readers are allowed to copy, distribute and communicate article's contents, provided the author's and Intangible Capital's names are included. It must not be used for commercial purposes. To see the complete license contents, please visit http://creativecommons.org/licenses/by-nc/3.0/. 